\title{
ANALISIS PENERAPAN AZAS KEADILAN; STUDI KASUS PELUNASAN DIPERCEPAT PEMBIAYAAN MURABAHAH BANK SYARIAH
}

\author{
Anasril Kambut \\ *Email : sahabatpenjelajah@gmail.com \\ Universitas Pamulang
}

\begin{abstract}
Murabaha financing is the provision of funds from Islamic Bank that uses a buying and selling scheme. It is practiced for a variety of financing products such as ; property financing, motor vehicle financing, productive financing, and others. Murabaha still dominates financing in islamic banking sector. Problems arise in the community regarding early repayment of murabaha financing. Based on previous review studies, Internal Rate of Return (IRR) can be used by Islamic Banks to obtain amount of payment that reflect justice. Conclusion of this qualitative research the Sharia Development Bank has successfully implemented a fair accelerated repayment policy, not burdening the Customer and not harming the Bank.
\end{abstract}

Keywords : murabaha, early repayment, fairness

\begin{abstract}
Abstrak
Pembiayaan Murabahah merupakan penyediaan dana dari Bank Syariah yang menggunakan skema jual beli. Skema ini dipraktikkan untuk berbagai macam produk pembiayaan meliputi ; pembiayaan properti, pembiayaan kendaraan bermotor, pembiayaan produktif, dan lain sebagainya. Skema Murabahah masih mendominasi pembiayaan pada sektor Perbankan Syariah. Muncul persoalan di masyarakat terkait pelunasan dipercepat pembiayaan murabahah. Berdasarkan studi review terdahulu, instrumen Internal Rate of Return (IRR) dapat digunakan Bank Syariah untuk mendapatkan nilai pelunasan yang mencerminkan azas keadilan. Kesimpulan penelitian kualitatif ini Bank Pembangunan Syariah mampu mengimplementasikan kebijakan pelunasan dipercepat yang adil, tidak memberatkan Nasabah dan tidak merugikan Bank.
\end{abstract}

Kata Kunci : murabahah, pelunasan dipercepat, keadilan 
Vol.2, No. 1, Jan. 2019

\section{PENDAHULUAN}

Bank Syariah merupakan lembaga bisnis yang berfungsi sebagai financial intermediary melalui kegiatan menghimpun dana dari masyarakat dan menyalurkan kembali dana tersebut dalam bentuk pembiayaan. Bank Syariah telah menjadi bagian sistem keuangan Indonesia sejak tahun 1992. Legitimasi bisnis yang dijalankan oleh Bank Syariah semakin kokoh dengan terbitnya Undang-Undang Republik Indonesia Nomor . 21 tahun 2008 tentang Perbankan Syariah (UU No. 21 Tahun 2008 tentang Perbankan Syariah).

Sebelum terbitnya UU No. 21 Tahun 2008 tentang perbankan Syariah, payung hukum keberadaan Perbankan Syariah dianggap lemah. Eksistensi Perbankan Syariah hanya mengacu 1 ayat pada pasal dalam peraturan yang mengatur tentang perbankan. Dalam Undang-Undang Nomor. 7 tahun 1992 tentang Perbankan (UU No. 7 Tahun 1992 Tentang Perbankan) pada pasal 1 ayat 12 dinyatakan : "Kredit adalah penyediaan uang atau tagihan yang dapat dipersamakan dengan itu, berdasarkan persetujuan atau kesepakatan pinjammeminjam antara bank dengan pihak lain yang mewajibkan pihak peminjam untuk melunasi hutangnya setelah jangka waktu tertentu dengan jumlah bunga, imbalan atau pembagian hasil keuntungan;"

Definisi kredit yang dirumuskan dalam ayat ini memunculkan istilah pembagian hasil keuntungan dimana hal ini merupakan substansi dari bisnis perbankan syariah yang berorientasi hasil keuntungan yang jamak dikenal sebagai imbal hasil atau bagi hasil. Rumusan secara langsung telah mengakomodir berdirinya PT Bank Muamalat Indonesia sebagai Bank Umum Syariah pertama di Indonesia pada 1 November 1991 atau 24 Rabi'us Tsani $1412 \mathrm{H}$ atau 4 bulan sebelum diundangkankanya UU No. 7 tahun 1992 tentan Perbankan.

Beberapa tahun kemudian ( \pm 6 tahun), Undang-Undang Nomor. 10 Tahun 1998 Tentang Perubahan atas Undang-Undang No. 7 tahun 1992 tentang Perbankan (UU No. 10 tahun 1998) resmi diundangkan pada 10 November 1998 oleh Pemerintah. Melalui UU No. 10 tahun 1998, angin segar eksistensi Perbankan Syariah dalam Sistem Keuangan Indonesia mulai terasa. Pada Pasal 1 ayat 3 terdapat kata "Prinsip Syariah" dalam pengaturan perbankan dimana dinyatakan ;"Bank Umum adalah bank yang melaksanakan kegiatan usaha secara konvensional dan atau berdasarkan Prinsip Syariah yang dalam kegiatannya memberikan jasa dalam lalu lintas pembayaran;"

Setelah berjalan selama dua dasawarsa, aset Bank Syariah Nasional (BUS/UUS/BPRS) saat ini ${ }^{1}$ tercatat sebesar Rp 444.426 milliar yang didukung dengan 202 Bank Syariah dan 2.635 jaringan kantor yang tersebar di seluruh wilayah Indonesia.

Porsi pembiayaan dari total aset Bank Syariah adalah sebesar 65,19\% atau Rp 289.731 milliar. Skim Murabahah masih mendominasi pembiayaan yang ada di Bank Syariah. Dari Rp 289.731 milliar, sebanyak 52,70\% (Rp 152.698 milliar) adalah pembiayaan dengan skim murabahah. Skim Murabahah adalah bagian dari transaksi jual beli. Jual beli dimana penjual menyampaikan secara

\footnotetext{
${ }^{1}$ Statistik Perbankan Syariah posisi 30 Juni 2018
} 
jelas jumlah keuntungan kepada pembeli. Dalam konteks perbankan, skema ini dipraktikkan secara cicil untuk berbagai macam produk pembiayaan. Misalnya ; pembiayaan properti, pembiayaan kendaraan bermotor, pembiayaan modal kerja, pembiayaan investasi, pembiayaan multiguna dan lain sebagainya.

Publik pernah diramaikan dengan keluhan di sosial media dari Nasabah Bank Syariah, ${ }^{2}$. Sebut saja Devi dan Bank Syariah Amin. Devi merupakan Nasabah Pembiayaan Properti berdasarkan Akad Murabahah yang berencana melakukan pelunasan dipercepat. Nasabah mempersoalkan kebijakan Bank Syariah Amin yang membebankan keseluruhan sisa harga jual/piutang murabahah. Keluhan Devi berubah menjadi suara kebencian yang diungkapkan dengan kalimat sakartik.

Seorang Dosen dari Universitas Pamulang melakukan penelitian lebih lanjut tentang kasus Devi dan Bank Syariah Amin. Dengan menggunakan pendekatan Internal Rate of Return (IRR), ia menyimpulkan Bank Syariah Amin berpotensi mencederai azas manfaat dan keadilan perlindungan konsumen sektor jasa keuangan syariah ${ }^{3}$. Kata 'berpotensi' digunakan karena pada faktanya persoalan Devi dan Bank Syariah Amin adalah pada tahap negosiasi awal. Di bagian akhir penelitian disimpulkan Bank Syariah umumnya memberikan potongan harga bagi Nasabah yang melakukan pelunasan pembiayaan dipercepat.

Penulis tertarik melakukan penelitian lebih lanjut yang terkait dengan kebijakan pelunasan dipercepat pembiayaan murabahah yang dipraktikkan oleh Bank Syariah. Penelitian akan difokuskan pada analisis penerapan azas keadilan pada kebijakan pelunasan dipercepat di salah satu Bank Syariah yang beroperasi di wilayah Jakarta.

\section{KERANGKA TEORITIS}

\section{Pendapatan Bank Syariah}

Bank Syariah memperoleh pendapatan melalui 3 aktivitas yaitu Penghimpunan Dana, Penyaluran Dana dan Penyediaan Jasa Keuangan Pendukung Lainnya.

1) Pendapatan pada aktivitas penghimpunan dana seperti Tabungan iB, Deposito iB dan lainnya diperoleh dengan menggunakan skim jasa (sewa) dan skim

\footnotetext{
${ }^{2}$ Irham Fachreza Anas. (2016). Lingkaran Setan Kpr dan Keadilan Dalam Pelunasan Pembiayaan Murabahah. https https://irham-anas.blogspot.com/2016/08/membedah-logika-bank-syariahsesi-3.html

${ }^{3}$ Irham Fachreza Anas. (2018). Titik Kritis Pelunasan Sebelum Jatuh Tempo Pembiayaan. Jurnal Akuntansi Berkelanjutan Indonesia Vol 1. Universitas Pamulang. hal 33
} 
kerjasama. Dalam hal ini juga termasuk aktifivitas yang muncul dari kegiatan Unit Tresuri di Bank Syariah.

2) Pendapatan pada aktivitas penyaluran dana seperti Kredit Pemilikan Rumah (KPR) iB, Pembiayaan Modal Kerja iB dan pembiayaan lainnya diperoleh dengan menggunakan skim jual beli (murabahah, istishna', salam), skim jasa/sewa (ijarah, ijarah muntahiya bit tamlik, ijarah mausufah fi dzimmah) dan skim kerjasama (mudharabah, musyarakah, musyarakah mutanaqishah) .

3) Pendapatan pada aktivitas layanan jasa keuangan pendukung lain seperti transfer, surat keterangan bank, safe deposit box dan lainnya diperoleh dengan menggunakan skim jasa (sewa).

\section{Pembiayaan Murabahah}

Murabahah adalah bagian dari skim jual beli. Murabahah berarti menjual suatu barang dengan menegaskan harga belinya kepada pembeli dan pembeli membayarnya dengan harga yang lebih sebagai laba. ${ }^{4}$ Dalam Surat Edaran Otoritas Jasa Keuangan Nomor 36/SEOJK.03/2015 tanggal 21 Desember 2015 Tentang Produk dan Aktivitas Bank Syariah dan Unit Usaha Syariah pada Lampiran IV halaman 56, Pembiayaan Murabahah pada Bank Syariah ; "Penyediaan dana atau tagihan yang dapat dipersamakan dengan itu untuk transaksi jual beli barang sebesar harga pokok ditambah margin berdasarkan persetujuan atau kesepakatan antara Bank dengan nasabah yang mewajibkan nasabah untuk melunasi hutang/kewajibannya".

Skema Murabahah dapat diterapkan dalam berbagai macam produk pembiayaan Bank Syariah. Misalnya, pembiayaan properti, pembiayaan kendaraan bermotor, pembiayaan modal kerja, pembiayaan investasi, pembiayaan multiguna dan lain sebagainya.

Merujuk pada Fatwa Dewan Syariah Nasional Majelis Ulama Indonesia (Fatwa DSN-MUI) No. 111 tentang Akad Jual Beli Murabahah bahwa jual beli murabahah boleh dilakukan dalam bentuk bai' al'murabahah al-'adiyyah maupun dalam bentuk bai' al-murabahah li al-amir bi al-syira. Bai' al'murabahah al-'adiyyah adalah akad jual beli murabahah yang dilakukan atas barang yang sudah dimiliki penjual pada saat barang tersebut ditawarkan kepada calon pembeli. Sedangkan, Bai' al-murabahah li al-amir bi al-syira adalah akad jual beli murabahah yang dilakukan atas dasar pesanan dari pihak calon pembeli.

\section{Pengakuan Keuntungan Metode :Flat, Efektif dan Anuitas}

Secara umum ada 2 (dua) metode perhitungan dan/atau pengakuan keuntungan (margin/fee/bagi hasil/bunga) pada transaksi keuangan yaitu metode: flat dan efektif. Dalam praktiknya ada modifikasi lain yang kenal dengan metode anuitas. $^{5}$

\footnotetext{
${ }^{4}$ Fatwa Dewan Syariah Nasional No. 4 tentang Murabahah

${ }^{5}$ Brosur Bank Indonesia ; Memahami Bunga Kredit
} 


\begin{tabular}{|c|r|r|r|r|}
\hline Bulan & $\begin{array}{c}\text { Pinjaman / } \\
\text { Pembiayaan }\end{array}$ & Pokok & $\begin{array}{c}\text { Bunga / } \\
\text { Keuntungan }\end{array}$ & Angsuran \\
\hline \multicolumn{5}{|c|}{$500,000,000$} \\
\hline 1 & $495,833,333$ & $4,166,667$ & $3,375,000$ & $7,541,667$ \\
\hline 2 & $491,666,667$ & $4,166,667$ & $3,375,000$ & $7,541,667$ \\
\hline 3 & $487,500,000$ & $4,166,667$ & $3,375,000$ & $7,541,667$ \\
\hline 4 & $483,333,333$ & $4,166,667$ & $3,375,000$ & $7,541,667$ \\
\hline 5 & $479,166,667$ & $4,166,667$ & $3,375,000$ & $7,541,667$ \\
\hline \multicolumn{5}{|c|}{ Metode Efektif (rate 13,25\%, 120 Bulan) } \\
\hline 1 & $495,833,333$ & $4,166,667$ & $5,520,833$ & $9,687,500$ \\
\hline 2 & $491,666,667$ & $4,166,667$ & $5,474,826$ & $9,641,493$ \\
\hline 3 & $487,500,000$ & $4,166,667$ & $5,428,819$ & $9,595,486$ \\
\hline 4 & $483,333,333$ & $4,166,667$ & $5,382,813$ & $9,549,479$ \\
\hline 5 & $479,166,667$ & $4,166,667$ & $5,336,806$ & $9,503,472$ \\
\hline \multicolumn{5}{|c|}{ Metode Anuitas (rate 13,25\%, 120 Bulan) } \\
\hline 1 & $497,981,388$ & $2,018,612$ & $5,520,833$ & $7,539,446$ \\
\hline 2 & $495,940,486$ & $2,040,901$ & $5,498,544$ & $7,539,446$ \\
\hline 3 & $493,877,050$ & $2,063,436$ & $5,476,010$ & $7,539,446$ \\
\hline 4 & $491,790,830$ & $2,086,220$ & $5,453,226$ & $7,539,446$ \\
\hline 5 & $489,681,575$ & $2,109,255$ & $5,430,190$ & $7,539,446$ \\
\hline
\end{tabular}

Tabel 1 Simulasi Perhitungan Flat, Efektif dan Anuitas

Dewan Syariah Nasional Majelis Ulama Indonesia (DSN-MUI) pada tanggal 21 Desember 2012 menerbitkan Fatwa No. 84/DSN-MUI/XII/2012 tentang Metode Pengakuan Keuntungan Al-Tamwil Bi Al-Murabahah (Pembiayaan Murabahah) Di Lembaga Keuangan Syariah. Fatwa ini mengatur tentang Metode Proporsional (flat) dan Metode Anuitas. Metode Proporsional (Thariqah Mubasyirah) adalah pengakuan keuntungan yang dilakukan secara proporsional atas jumlah piutang (harga jual, tsaman) yang berhasil ditagih dengan mengalikan persentase keuntungan terhadap jumlah piutang yang berhasil ditagih (al-atsman al-muhashshalah). Sedangkan, Metode Anuitas (Thariqah alHisab al-Tanazuliyyah / Thariqah al- Tanaqushiyyah) adalah pengakuan keuntungan yang dilakukan secara proporsional atas jumlah sisa harga pokok yang belum ditagih dengan mengalikan persentase keuntungan terhadap jumlah sisa harga pokok yang belum ditagih (al-atsman al-mutabaqqiyah).

Pengakuan keuntungan al-Tamwil bi al-Murabahah dalam bisnis yang dilakukan oleh Lembaga Keuangan Syariah boleh dilakukan secara Proporsional dan secara Anuitas selama sesuai dengan 'urf (kebiasaan) yang berlaku di kalangan Lembaga Keuangan Syariah.

\section{Internal Rate of Return (IRR)}

Internal Rate of Return (IRR) atau Tingkat Laba Internal adalah tingkat laba yang membuat nilai sekarang arus kas di masa depan persis menyamakan investasi (awal). ${ }^{6}$ Metode ini akan menghitung suatu proyek dengan cara menyamakan nilai present value (saat ini) dari ekspektasi cash flow (arus kas) dan nilai investasi awal.

Fungsi IRR digunakan untuk mengetahui tingkat keuntungan dengan yang menyamakan nilai sekarang investasi (outflow) dengan nilai sekarang penerimaan kas bersih (inflow) di masa mendatang. Bentuk umum fungsi IRR dalam

\footnotetext{
${ }^{6}$ Ciaran Walsh. (2012). Key Management Ratios. Edisi Keempat Penerjemah Agus Dharma. Jakarta. Esensi Erlangga Group. hal. 245
} 
microsoft excel adalah : = IRR (range, perkiraan) ${ }^{7}$. Dengan range menyatakan arus kas. Perkiraan/guess diisi dengan sembarang nilai antara 0 dan 1 . Fungsi IRR melakukan perhitungan melalui proses iterasi (mencoba dan mendekati secara berulang). Jika setelah 20 kali interasi excel belum memperoleh hasil dengan ketelitian 0.0000001, fungsi itu memberikan pesan kesalahan \#NUM. ${ }^{8}$

\begin{tabular}{|c|c|c|}
\hline & Investasi Awal & $(\operatorname{Rp} 5.000 .000 .000)]^{*}$ \\
\hline & Pengembalian Tahun Ke 1 & Rp1.500.000.000 \\
\hline & Pengembalian Tahun Ke 2 & Rp1.500.000.000 \\
\hline & Pengembalian Tahun $\mathrm{Ke} 3$ & Rp1.500.000.000 \\
\hline & Pengembalian Tahun $\mathrm{Ke} 4$ & Rp1.500.000.000 \\
\hline & Pengembalian Tahun $\mathrm{Ke} 5$ & Rp1.500.000.000 \\
\hline & \multicolumn{2}{|c|}{ IRR =IRR(E5:E10;0,01) } \\
\hline & & IRR(values; [guess]) \\
\hline \multicolumn{2}{|c|}{ Investasi Awal } & $(\operatorname{Rp} 5.000 .000 .000) *$ \\
\hline \multicolumn{2}{|c|}{ Pengembalian Tahun Ke 1} & Rp1.500.000.000 \\
\hline \multicolumn{2}{|r|}{ Pengembalian Tahun Ke 2} & Rp1.500.000.000 \\
\hline \multicolumn{2}{|c|}{ Pengembalian Tahun Ke 3} & Rp1.500.000.000 \\
\hline \multicolumn{2}{|r|}{ Pengembalian Tahun Ke 4} & Rp1.500.000.000 \\
\hline \multicolumn{2}{|r|}{ Pengembalian Tahun Ke 5} & Rp1.500.000.000 \\
\hline \multicolumn{3}{|c|}{ IRR } \\
\hline \multicolumn{3}{|c|}{ *Kas keluar sehingga di-minus-kan } \\
\hline
\end{tabular}

Tabel 2 Simulasi Penggunaan IRR dalam Microsoft Excel

IRR untuk angsuran pembiayaan dengan aliran kas masuk bulanan harus dikalikan 12 atau di-setahun-kan. Fungsi IRR berubah menjadi ; = IRR (range, perkiraan)*12.

\section{Kesepakatan Pasar dan Kesepakatan Rasa Keadilan}

Matthew Rabin dalam penelitian Incorporating Fairness into Game Theory and Economics menyebutkan dalam setiap transaksi ada dua kesepakatan yang harus terpenuhi, yaitu Kesepakatan Pasar (market equlibria) dan Kesepakatan Rasa Keadilan (fairness equlibria). Kesepakatan antara perusahaan besar dengan para pelanggan kecil yang merasa terekploitasi merupakan contoh tidak tercapainya kesepakatan rasa keadilan. Para pelanggan kecil karena tidak punya pilihan lain mereka harus menerima kesepakatan pasar dari perusahaan besar. Transaksi ini tidak akan stabil atau berkelanjutan dan cenderung rapuh karena konsumen merasa tidak nyaman. Ketika ada pilihan lain yang dapat memberikan rasa

\footnotetext{
${ }^{7}$ Dalam Microsoft Excel 2010 formula IRR adalah = IRR (values; [ guess])

8 Budianto, Aris. Modul Praktikum KKPI Microsoft Excel 2007 - Untuk Kelas : X Semester 2. Sidareja. SMK Tamtama 1 hal 39
} 
keadilan walaupun kadang belum tentu lebih baik maka mereka tetap akan berpindah. $^{9}$

Praktik bisnis keuangan syariah harus mampu menerapkan/mewujudkan keadilan untuk kepentingan semua pihak, khususnya konsumen (nasabah) dan pelaku usaha (Bank syariah). Keadilan berarti kepentingan konsumen dan pelaku usaha dapat diwujudkan secara maksimal dan memberikan kesempatan kepada mereka kesempatan untuk memperoleh hak dan melaksanakan kewajiban masingmasing secara adil. Inilah yang dimaksud dengan asas keadilan sebagaimana diamanahkan Undang-Undang Republik Indonesia nomor 8 tahun 1988 tentang Perlindungan Konsumen (UU No. 8 Tahun 1999 tentang Perlindungan Konsumen). ${ }^{10}$ Berkaitan dengan pelunasan dipercepat pembiayaan murabahah, model perhitungan yang mencerminkan asas keadilan adalah dengan pola sisa saldo pokok dimana nilai Rate of Return atau RR efektif pelunasan harus sama dengan RR efektif awal. ${ }^{11}$ Perhitungan jumlah pelunasan dapat dilakukan dengan menggunakan instrumen Internal Rate of Return (IRR).

\section{Potongan Pelunasan Pembiayaan Murabahah}

Dalam Surat Edaran Otoritas Jasa Kuangan No. 36/SEOJK.03/2015 pada Lampiran IV halaman 58-59 dinyatakan ; '4.10 Bank dapat memberikan potongan tagihan (cicilan) murabahah yang belum dilunasi apabila nasabah melakukan pembayaran cicilan tepat waktu dan/atau mengalami penurunan kemampuan membayar, dengan syarat tidak boleh diperjanjikan dalam akad dan besarnya potongan diserahkan kepada kebijakan Bank. Dalam hal Bank memberikan potongan tagihan murabahah yang belum dilunasi karena nasabah membayar cicilan tepat waktu maka Bank harus memiliki kebijakan dan kriteria mengenai nasabah yang membayar cicilan tepat waktu. Mekanisme pemberian potongan tagihan murabahah mengacu pada Pedoman Akuntansi Perbankan Syariah Indonesia (PAPSI).'

Accounting and Auditing Organization for Islamic Financial Institutions (selanjutnya ditulis 'AAOIFI') membolehkan Lembaga Keuangan Syariah yang ingin melepaskan bagian keuntungannya sepanjang tidak diperjanjikan dalam perjanjian kontraktual (perjanjian pembiayaan); '5/9 It is permissible for the institution to give up part of selling price if the customer pays early, provided this was not part of the contractual agreement. ${ }^{, 12}$

DR. Erwandi Tarmizi menulis bahwa potongan harga kredit karena pelunasan sebelum jatuh tempo hukumnya boleh dengan syarat pemotongan harga tidak dicantumkan dalam akad jual-beli. Adapun alasan pelarangan pencantuman potongan pelunasan dalam akad sebagaimana dikutip dari bukunya berjudul Harta Haram Muamalat Kontemporer meliputi ; i) harga menjadi tidak jelas, sedangkan

\footnotetext{
${ }^{9}$ Oni Sahroni. Ushul Fikih Muamalah; Kaidah-Kaidah Ijtihad dan Fatwa Dalam Ekonomi Islam. Jakarta : Rajawali Press. 2017. hal 118

${ }^{10}$ Irham Fachreza Anas. Op Cit. hal 37

${ }^{11}$ Ibid hal 40

12 Accounting and Auditing Organization for Islamic Financial Institutions. (2015). Shari'a Standards. Kingdom of Bahrain. hal 214
} 
syarat sah jual beli harga dan barang harus jelas dan ii) akan terjadi riba jahiliyah dalam akad jual beli tersebut. Sebab, jika nasabah tidak jadi melunasi dipercepat maka harga jual menjadi naik. ${ }^{13}$

\section{METODE RISET}

\section{Jenis, Pendekatan dan Model Penelitian}

Jenis penelitian ini adalah Penelitian Lapangan, yaitu penelitian yang bertujuan untuk mengumpulkan data dan informasi dengan bantuan berbagai macam material yang ada di lapangan (luar perpustakaan), yaitu penelitian pada Bank Syariah. Secara keseluruhan pendekatan penelitian yang digunakan adalah metode Empiris, yaitu meneliti kebijakan pelunasan dipercepat pembiayaan murabahah yang dipraktikkan oleh salah satu Bank Syariah yaitu Bank Pembangunan Syariah ${ }^{14}$.

Model penelitian ini adalah Kualitatif, yaitu penelitian yang tidak mengadakan penghitungan matematis, statistik dan lain sebagainya, melainkan menggunakan penekanan ilmiah ${ }^{15}$ atau penelitian yang menghasilkan penemuanpenemuan yang tidak dapat dicapai dengan menggunakan prosedur-prosedur statistik atau dengan cara-cara lain dari kuantifikasi. ${ }^{16}$ Bilamana dalam penelitian ini terdapat angka-angka, model perhitungan, dan lain sebagainya yang berhubungan dengan kuantitatif, maka hal tersebut dilakukan hanya sebatas untuk memperkuat analisis bukan untuk mencari hubungan antara variabel.

\section{Data, Pengumpulan Data dan Teknik Analisis}

Sumber data yang digunakan adalah primer dan sekunder. Data Primer bersumber dari 4 (empat) Praktisi Bank Pembangunan Syariah. Sedangkan, Data Sekunder meliputi seluruh literatur yang berhubungan dengan instrumen keuangan, hukum Islam dan hukum positif yang berlaku dalam pembiayaan dan literatur lain yang dapat memberikan informasi tambahan pada judul yang diangkat dalam penelitian ini, misalnya ; brosur, artikel, berita dan lain sebagainya.

Teknik pengumpulan data yang digunakan pada penelitian ini sebagai berikut ;

1. Studi Dokumentasi Naskah (studi pustaka); yaitu pengumpulan data dengan cara mengkaji Daftar Angsuran, Fatwa DSN-MUI, POJK, dan semua bahan tertulis lainnya, termasuk artikel yang diakses dari internet.

2. Wawancara ; dilakukan dengan melibatkan pihak-pihak yang dianggap kredibel atau punya keterkaitan dengan judul penelitian. Wawancara dilakukan dengan menggunakan Lembar Pedoman Wawancara. Adapun

\footnotetext{
${ }^{13}$ Erwandi Tarmizi. (2016). Harta Haram Muamalat Komtemporer. Bogor. Berkat Mulia Insani. hal 458-459

${ }^{14}$ Nama disamarkan sesuai permintaan responden

${ }^{15}$ Lexy Moleong, (1997). Metodologi Penelitian Kualitatif ,ed: revisi. Bandung. PT Remaja Rosda Karya. hal. 6

${ }^{16}$ Syamsir Salam dan Jaenal Aripin. (2004). Metodologi Penelitian Sosial. Jakarta. UIN Jakarta Press. hal 30
} 
pihak-pihak yang dipilih sebagai responden meliputi : 4 orang praktisi Bank Pembangunan Syariah (Manager Pemasaran Produk Konsumer, Manager Pemasaran Produk Ritel, Manager Pemasaran Produk Korporasi dan Kepala Unit Pemasaran Mikro).

Teknik analisa yang digunakan dalam penelitian kualitatif ini adalah Deskriptif Analisis. Deskriptif berarti teknik analisa dengan cara memberikan gambaran umum mengenai data penelitian meliputi ; perhitungan pembiayaan, intisari wawancara dan kebijakan pelunasan pembiayaan dipercepat (early payment). Gambaran data disusun berdasarkan kerangka pemikiran penulis. Gambaran data akan dianalisa secara kritis untuk menghasilkan kesimpulan.

\section{Analisis Data}

Data penelitian diperoleh dalam periode waktu Bulan Agustus 2018. Seluruh data yang berhasil diperoleh akan di susun ulang sehingga menyatu dalam rangkaian pembahasan. Berkaitan dengan permintaan kerahasiaan identitas pihakpihak yang menjadi responden, maka analisa fakta dalam penelitian ini dibuat dengan tidak mencantumkan identitas Praktisi serta nama Bank Syariah.

\section{PEMBAHASAN}

\section{Pembiayaan Murabahah Program Khusus (Single Rate - Anuitas)}

Pembiayaan Murabahah Program Khusus adalah penyediaan dana untuk kebutuhan konsumsi, seperti pembelian tanah, kendaraan, alat elektronik dan lainnya dengan tenor maksimal 10 tahun. Produk ini disediakan untuk instansi yang telah bekerjasama secara notarial dengan limit mencapai Rp 500.000.000,00. Keunggulan pembiayaan konsumsi ini adalah tidak adanya penyerahan agunan kepada Bank.

Simulasi angsuran pembiayaan dengan limit Rp 500.000.000,00 selama 5 tahun (mulai Januari 2016) dengan pengakuan keutungan secara anuitas setara $18 \%$ eff/p.a, sebagai berikut ;

Tabel 3 Simulasi Angsuran Pembiayaan Murabahah Program Khusus

\begin{tabular}{|l|r|}
\hline \multicolumn{2}{|l|}{ Pembiayaan Murabahah Program Khusus } \\
\hline A. Harga Perolehan & 600.000 .000 \\
\hline B. Margin & 261.802 .823 \\
\hline C. Harga Jual & 861.802 .823 \\
\hline D. Uang Muka Nasabah & 100.000 .000 \\
\hline E. Piutang Murabahah & 761.802 .823 \\
\hline & \\
\hline F. Pembiayaan Bank & 500.000 .000 \\
\hline G. Angsuran : & 12.696 .714 \\
\hline
\end{tabular}




\begin{tabular}{|l|r|l|}
\hline PEMBIAYAAN & $500.000 .000,00$ & RUPIAH \\
\hline JANGKA WAKTU & 60 & BULAN \\
\hline EQUNVALEN RATE MARGIN & $18,00 \%$ |ANGSURAN : & 12.696 .714 \\
\hline
\end{tabular}

\begin{tabular}{|r|r|r|r|r|r|r|r|}
\hline \multicolumn{5}{|c|}{ Jadwal Angsuran Kepada Nasabah } & \multicolumn{4}{|c|}{ Internal Akuntansi Bank (Anuitas) } \\
\hline No. & Bulan & Hutang Nasabah & Angsuran & Ang. Pokok & Ang. Margin & Pokok & \multicolumn{1}{c|}{ Margin } \\
\hline & Jan-16 & 761.802 .823 & & & & 500.000 .000 & 261.802 .823 \\
\hline 1 & Feb-16 & 749.106 .109 & 12.696 .714 & 5.196 .714 & 7.500 .000 & 494.803 .286 & 254.302 .823 \\
\hline 2 & Mar-16 & 736.409 .395 & 12.696 .714 & 5.274 .664 & 7.422 .049 & 489.528 .622 & 246.880 .774 \\
\hline 3 & Apr-16 & 723.712 .682 & 12.696 .714 & 5.353 .784 & 7.342 .929 & 484.174 .837 & 239.537 .844 \\
\hline 4 & Mei-16 & 711.015 .968 & 12.696 .714 & 5.434 .091 & 7.262 .623 & 478.740 .746 & 232.275 .222 \\
\hline 5 & Jun-16 & 698.319 .254 & 12.696 .714 & 5.515 .603 & 7.181 .111 & 473.225 .144 & 225.094 .110 \\
\hline 6 & Jul-16 & 685.622 .541 & 12.696 .714 & 5.598 .337 & 7.098 .377 & 467.626 .807 & 217.995 .733 \\
\hline 7 & Agust-16 & 672.925 .827 & 12.696 .714 & 5.682 .312 & 7.014 .402 & 461.944 .496 & 210.981 .331 \\
\hline 8 & Sep-16 & 660.229 .113 & 12.696 .714 & 5.767 .546 & 6.929 .167 & 456.176 .949 & 204.052 .164 \\
\hline 9 & Okt-16 & 647.532 .399 & 12.696 .714 & 5.854 .059 & 6.842 .654 & 450.322 .890 & 197.209 .509 \\
\hline 10 & Nop-16 & 634.835 .686 & 12.696 .714 & 5.941 .870 & 6.754 .843 & 444.381 .020 & 190.454 .666 \\
\hline 11 & Des-16 & 622.138 .972 & 12.696 .714 & 6.030 .998 & 6.665 .715 & 438.350 .021 & 183.788 .951 \\
\hline 12 & Jan-17 & 609.442 .258 & 12.696 .714 & 6.121 .463 & 6.575 .250 & 432.228 .558 & 177.213 .701 \\
\hline 58 & Nop-20 & 25.393 .427 & 12.696 .714 & 12.142 .083 & 554.631 & 24.833 .292 & 560.136 \\
\hline 59 & Des-20 & 12.696 .714 & 12.696 .714 & 12.324 .214 & 372.499 & 12.509 .078 & 187.636 \\
\hline 60 & Jan-21 & $(0)$ & 12.696 .714 & 12.509 .078 & 187.636 & $(0)$ & \\
\hline & & IRR & $18,00 \%$ & & & & 0 \\
\hline
\end{tabular}

Pelunasan dipercepat Pembiayaan Murabahah Program Khusus di Bank Pembangunan Syariah berlaku ketentuan bahwa nilai pelunasan adalah sisa pokok pembiayaan ditambah 1 (satu) kali margin. Kebijakan ini ditetapkan dalam Standar Operasi Prosedur Bank. Skenario pelunasan pembiayaan dipercepat dilakukan di bulan ke-12 dengan simulasi sebagai berikut ;

\section{Tabel 4 Simulasi Pelunasan Dipercepat Pembiayaan Murabahah Program Khusus}

\begin{tabular}{|c|r|r|}
\hline \multicolumn{3}{|c|}{ Pelunasan Dipercepat } \\
\hline Bulan & & \\
\hline 1 & 12.696 .714 & \\
\hline 2 & 12.696 .714 & \\
\hline 3 & 12.696 .714 & \\
\hline 4 & 12.696 .714 & \\
\hline 5 & 12.696 .714 & \\
\hline 6 & 12.696 .714 & \\
\hline 7 & 12.696 .714 & \\
\hline 8 & 12.696 .714 & \\
\hline 9 & 12.696 .714 & \\
\hline 10 & 12.696 .714 & \\
\hline 11 & 12.696 .714 & \\
\hline 12 & 622.138 .972 & \\
\hline IRR & $47,96 \%$ & \\
\hline Sisa hutang Bulan ke -11 & 622.138 .972 \\
\hline Nilai Pelunasan & $:$ & 622.138 .972 \\
\hline Potongan Pelunasan & \\
\hline
\end{tabular}

\begin{tabular}{|c|c|c|}
\hline \multicolumn{3}{|c|}{ Pelunasan Dipercepat } \\
\hline \multicolumn{3}{|l|}{ Bulan } \\
\hline 1 & 12.696 .714 & \\
\hline 2 & 12.696 .714 & \\
\hline 3 & 12.696 .714 & \\
\hline 4 & 12.696 .714 & \\
\hline 5 & 12.696 .714 & \\
\hline 6 & 12.696 .714 & \\
\hline 7 & 12.696 .714 & \\
\hline 8 & 12.696 .714 & \\
\hline 9 & 12.696 .714 & \\
\hline 10 & 12.696 .714 & \\
\hline 11 & 12.696 .714 & \\
\hline 12 & 444.925 .271 & \\
\hline IRR & $18,00 \%$ & \\
\hline \multicolumn{2}{|c|}{ Sisa Pokok Bulan Ke-11 } & 438.350 .021 \\
\hline \multicolumn{2}{|c|}{ Margin Bulan $\mathrm{Ke}-12$} & 6.575 .250 \\
\hline \multicolumn{2}{|c|}{ Nilai Pelunasan : } & 444.925 .271 \\
\hline \multicolumn{2}{|c|}{ Potongan Pelunasan } & 177.213 .701 \\
\hline
\end{tabular}

Murabahah adalah menjual suatu barang dengan menegaskan harga belinya kepada pembeli dan pembeli membayarnya dengan harga yang lebih sebagai laba. Nasabah yang dibiayai untuk mendapatkan barang dengan Akad Murabahah secara transaksional sejatinya melakukan transaksi jual beli secara tempo atau angsur 
dalam jangka waktu tertentu. Pada saat akad murabahah secara tempo disepakati yang diiringi dengan penyerahan barang, maka jual beli tersebut telah sempurna sehingga kemudian muncul hubungan hutang-piutang. Nasabah secara prinsip syariah dan/atau secara legal formal dinyatakan telah berhutang kepada Bank Syariah sebesar harga jual yang belum dilunasi.

Bank Pembangunan Syariah memiliki hak yang dijamin oleh Prinsip Syariah untuk menetapkan jumlah pelunasan sebesar Rp 622.138.972 (sisa hutang di bulan ke - 11). Jika hal tersebut dilakukan, maka angka prosentase keuntungan rate of return "IRR" berubah naik dari $18,00 \%$ menjadi $47,96 \%$. Tentu hal ini sangat memberatkan nasabah dan berpotensi mencederai azas keadilan. Pada prakteknya, kebijakan pelunasan sisa pokok ditambah 1 (satu) kali margin berdampak pada menurunnya nilai pelunasan yang wajib diselesaikan Nasabah menjadi Rp 444.925.271. Adapun sisa tagihan sebesar Rp 177.213.701 ditetapkan Bank Pembangunan Syariah sebagai potongan pelunasan dipercepat bagi Nasabah.

Berdasarkan simulasi IRR, nilai pelunasan Rp 444.925.271 menghasilkan angka "IRR" yang sama pada saat awal akad yaitu setara 18,00\%. Bank Pembangunan Syariah untuk produk ini mampu mewujudkan azas keadilan dalam pelunasan dipercepat yaitu dengan menetapkan nilai pelunasan yang tidak memberatkan Nasabah dan tidak merugikan Bank Syariah.

\section{Pembiayaan Murabahah Properti (Multi Rate - Anuitas)}

Pembiayaan Murabahah Properti di Bank Pembangunan Syariah adalah penyediaan dana untuk kepemilikan properti dan/atau keperluan konsumsi lainnya dengan beragun properti. Pembiayaan Properti ditujukan bagi para pegawai: Pegawai Negeri Sipil (PNS), Badan Usaha Milik Negara (BUMN) atau Badan Usaha Milik Daerah (BUMD), Swasta terpilih, pengusaha dan profesional tertentu. Tenor pembiayaan yang ditawarkan Bank Pembangunan Syariah maksimal 20 tahun.

Secara umum Bank Syariah menerapkan single rate (1 angka persentase) dalam menghitung keuntungan usaha. Dampak dari single rate adalah angsuran sama sampai dengan jatuh tempo pembiayaan. Namun, berdasarkan wawancara Bank Pembangunan Syariah yang menerapkan multi rate untuk pembiayaan properti. Dalam menetapkan multi rate, keuntungan dihitung menggunakan lebih dari 1 angka persentase. Dampak penerapan multi rate adalah adanya perbedaan angsuran pada periode tertentu yang disepakati pada saat perjanjian atau tercantum dalam perjanjian pembiayaan.

Berikut simulasi Pembiayaan Properti Bank Pembangunan Syariah dengan multi rate untuk limit $\mathrm{Rp} 750.000 .000,00$ dengan tenor 15 tahun di mulai Januari 2016. 
Vol.2, No. 1, Jan. 2019

Tabel 5 Simulasi Tabel Angsuran Pembiayaan Murabahah Multi Rate

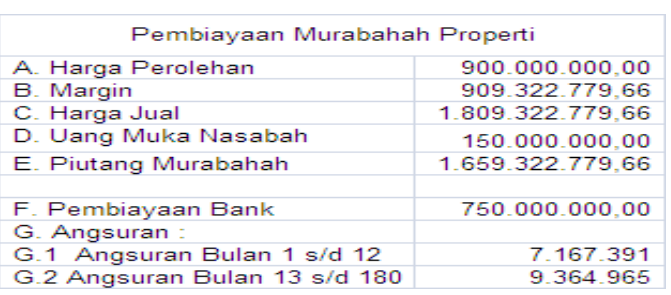

\begin{tabular}{|c|c|c|}
\hline PEMBIAYAAN & $750.000 .000,00$ & RUPIAH \\
\hline JANGKA WAKTU & 180 & BULAN \\
\hline EQUIVALEN RATE MARGIN Tahun $\mathrm{Ke}-1$ & \begin{tabular}{ll|l}
$8,00 \%$ & ANGSURAN :
\end{tabular} & 7.167 .391 \\
\hline EQUIVALEN RATE MARGIN Tahun $\mathrm{Ke}-2 \mathrm{~s} / \mathrm{d} 15$ & $\begin{array}{l}13,00 \% \\
\text { ANGSURAN : }\end{array}$ & 9.364 .965 \\
\hline
\end{tabular}

\begin{tabular}{|r|r|r|r|r|r|r|r|}
\hline \multicolumn{5}{|c|}{ Jadwal Angsuran Kepada Nasabah } & \multicolumn{4}{|c|}{ Internal Akuntansi Bank (Anuitas) } \\
\hline No. & Bulan & Hutang Nasabah & \multicolumn{1}{|c|}{ Angsuran } & Ang. Pokok & Ang. Margin & \multicolumn{1}{|c|}{ Pokok } & \multicolumn{1}{|c|}{ Margin } \\
\hline & Jan-16 & 1.659 .322 .780 & & & $750.000 .000,00$ & $909.322 .779,66$ \\
\hline 1 & Feb-16 & 1.652 .155 .389 & 7.167 .391 & 2.167 .391 & 5.000 .000 & 747.832 .609 & 904.322 .780 \\
\hline 2 & Mar-16 & 1.644 .987 .998 & 7.167 .391 & 2.181 .840 & 4.985 .551 & 745.650 .769 & 899.337 .229 \\
\hline 3 & A.pr-16 & 1.637 .820 .608 & 7.167 .391 & 2.196 .386 & 4.971 .005 & 743.454 .384 & 894.366 .224 \\
\hline 4 & Mei-16 & 1.630 .653 .217 & 7.167 .391 & 2.211 .028 & 4.956 .363 & 741.243 .356 & 889.409 .861 \\
\hline 5 & Jun-16 & 1.623 .485 .827 & 7.167 .391 & 2.225 .768 & 4.941 .622 & 739.017 .588 & 884.468 .239 \\
\hline 6 & Jul-16 & 1.616 .318 .436 & 7.167 .391 & 2.240 .607 & 4.926 .784 & 736.776 .981 & 879.541 .455 \\
\hline 7 & Agust-16 & 1.609 .151 .045 & 7.167 .391 & 2.255 .544 & 4.911 .847 & 734.521 .437 & 874.629 .608 \\
\hline 8 & Sep-16 & 1.601 .983 .655 & 7.167 .391 & 2.270 .581 & 4.896 .810 & 732.250 .856 & 869.732 .799 \\
\hline 9 & Okt-16 & 1.594 .816 .264 & 7.167 .391 & 2.285 .718 & 4.881 .672 & 729.965 .138 & 864.851 .126 \\
\hline 10 & Nop-16 & 1.587 .648 .873 & 7.167 .391 & 2.300 .956 & 4.866 .434 & 727.664 .181 & 859.984 .692 \\
\hline 11 & Des-16 & 1.580 .481 .483 & 7.167 .391 & 2.316 .296 & 4.851 .095 & 725.347 .885 & 855.133 .598 \\
\hline 12 & Jan-17 & 1.573 .314 .092 & 7.167 .391 & 2.331 .738 & 4.835 .653 & 723.016 .147 & 850.297 .945 \\
\hline 29 & Jun-18 & 1.414 .109 .690 & 9.364 .965 & 1.820 .597 & 7.544 .368 & 694.582 .589 & 719.527 .101 \\
\hline 30 & Jul-18 & 1.404 .744 .725 & 9.364 .965 & 1.840 .320 & 7.524 .645 & 692.742 .269 & 712.002 .456 \\
\hline & & IRR & $12,13 \%$ & & & & \\
\hline
\end{tabular}

\begin{tabular}{|c|c|c|}
\hline $\begin{array}{c}\text { Angsuran Fase Pertama } \\
\text { Rp } 7.167 .391 \\
\text { (bulan ke } 1 \text { s/d 12) }\end{array}$ & $\begin{array}{c}\text { Angsuran Fase Kedua } \\
\text { Rp } 9.364 .965 \\
\text { (bulan ke } 25 \text { s/d 180) }\end{array}$ & $\begin{array}{c}\text { Rate of Return } \\
\text { Akumulasi }\end{array}$ \\
\hline setara $8,00 \%$ eff $/ p . a$ & setara $13,00 \%$ eff $/ p . a$ & $\begin{array}{c}\text { setara } 12,13 \% \text { eff } \\
\text { /p.a }\end{array}$ \\
\hline
\end{tabular}

Dari seluruh RR tersebut, Penulis memilih RR terakhir sebesar 12,13\% efektif per tahun untuk digunakan sebagai dasar RR awal untuk pelunasan dipercepat. Sebab, RR tersebut merupakan akumulasi dari seluruh aliran kas masuk, atau aliran kas masuk sejak awal periode pembiayaan. Pelunasan dipercepat Pembiayaan Murabahah Properti di Bank Pembangunan Syariah berlaku ketentuan ; 


\section{Promo}

1. Pelunasan Dipercepat sebelum 60 Bulan : Sisa Pokok Pembiayaan ditambah (3 \% $\mathrm{x}$ pokok pembiayaan).

2. Pelunasan Dipercepat setelah 60 Bulan : Sisa Pokok Pembiayaan ditambah 1 (satu) kali margin.

3. Kebijakan dicantumkan dalam Surat Petunjuk Teknis Program Promo.
1. Pelunasan Dipercepat sebelum 12 Bulan : Sisa Pokok Pembiayaan ditambah 3 kali margin.

2. Pelunasan Dipercepat setelah 12 Bulan : Sisa Pokok Pembiayaan ditambah 1 (satu) kali margin.

3. Kebijakan dicantumkan dalam Standar Operasi Prosedur Bank.

Fokus analisa sub bab ini hanya pada kebijakan sisa pokok pembiayaan ditambah 3,00\% dikali sisa pokok pembiayaan untuk pelunasan pembiayaan Promo sebelum 60 bulan. Skenario pelunasan pembiayaan dipercepat dilakukan bulan ke-30 dengan simulasi sebagai berikut ;

\section{Tabel 6 Simulasi Pelunasan Dipercepat Properti Program Promo sebelum bulan 60 Bulan}

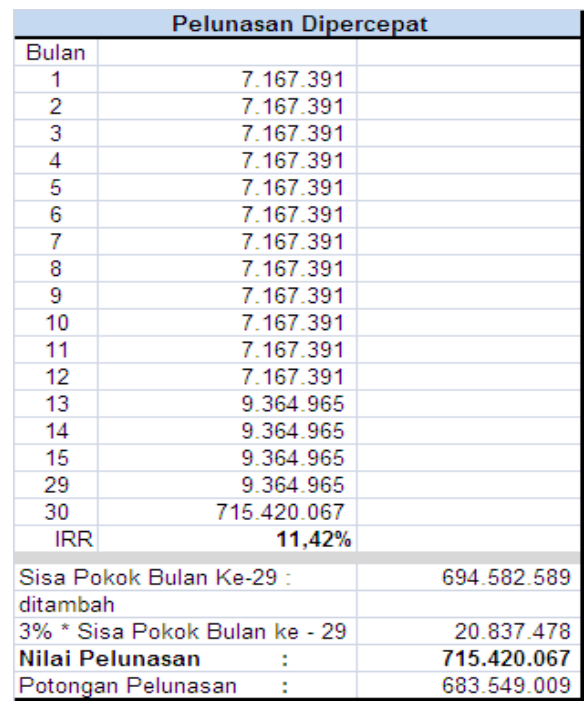

\begin{tabular}{|c|c|c|}
\hline \multicolumn{3}{|c|}{ Pelunasan Dipercepat Dengan RR 12,13\% } \\
\hline \multicolumn{3}{|l|}{ Bulan } \\
\hline 1 & 7.167 .391 & \\
\hline 2 & 7.167 .391 & \\
\hline 3 & 7.167.391 & \\
\hline 4 & 7.167.391 & \\
\hline 5 & 7.167.391 & \\
\hline 6 & 7.167 .391 & \\
\hline 7 & 7.167.391 & \\
\hline 8 & 7.167.391 & \\
\hline 9 & 7.167 .391 & \\
\hline 10 & 7.167 .391 & \\
\hline 11 & 7.167 .391 & \\
\hline 12 & 7.167.391 & \\
\hline 13 & 9.364 .965 & \\
\hline 14 & 9.364 .965 & \\
\hline 15 & 9.364 .965 & \\
\hline 29 & 9.364 .965 & \\
\hline 30 & 730.560 .681 & \\
\hline IRR & $12,13 \%$ & \\
\hline \multicolumn{2}{|c|}{ Sisa Pokok Bulan Ke-29 } & 694.582 .589 \\
\hline Margin & Bulan Ke-30 & 7524645 \\
\hline Margin & Bulan Ke-31 & 7.504 .708 \\
\hline Margin & Bulan Ke-32 & 7.484 .555 \\
\hline Margin & Bulan $\mathrm{Ke}-33$ & 7.464 .184 \\
\hline Margin & Bulan $\mathrm{Ke}-34$ & 6.000 .000 \\
\hline Nilai Pe & elunasan & 730.560 .681 \\
\hline Potonga & an Pelunasan & 683.549 .009 \\
\hline
\end{tabular}

Kebijakan sisa pokok pembiayaan ditambah 3,00\% dikali sisa pokok pembiayaan untuk pelunasan pembiayaan Promo sebelum 60 bulan juga berdampak pada menurunnya nilai IRR dari semula 12,13\% menjadi 11,42\%. Nasabah diwajibkan menyelesaikan tagihan pelunasan sebesar Rp 715.420.067. Bank Pembangunan Syariah tidak menerapkan kebijakan yang sama untuk pelunasan dipercepat Pembiyaan Murabahah Properti sebagaimana produk Pembiayaan Murabahah Program Khusus. Menuruk responden, pada Program Promo Bank telah menurunkan tingkat keuntungan hingga single digit di tahun 
pertama. Saat ini (Agustus 2018) Bank Pembangunan Syariah sedang menyiapkan Promo Akhir tahun dengan multi rate secara tiering single digit hingga tahun 60 bulan.

Berangkat dari perspektif persamaan angka IRR pelunasan dan IRR awal, penulis menyimpulkan kebijakan pelunasan dipercepat produk Pembiayaan Murabahah Program Promo sebelum 60 bulan mencederai azas keadilan di sisi Bank Syariah. Sebab, angka RR akumulasi dari seluruh aliran kas masuk, atau aliran kas masuk sejak awal periode pembiayaan adalah $12,13 \%$, bukan $11,42 \%$. Keadilan dalam perspektif perlindungan konsumen tidak hanya berorientasi pada kepentingan konsumen semata, melainkan juga kepentingan pelaku usaha. Bank Syariah sebagai pelaku usaha juga harus diberi kesempatan untuk memperoleh hak keuntungannya. Dari simulasi tabel 6 di atas dapat diketahui bahwa nilai pelunasan dipercepat yang adil adalah sebesar Rp 730.560.681 dengan angka IRR pelunasan sama dengan IRR awal yaitu sebesar 12,13\%.

Namun demikian, Bank Pembangunan Syariah dapat mempertimbangkan untuk tetap memberikan insentif berupa pengurangan nilai pelunasan sebagaimana perhitungan awal dengan IRR sebesar 11,42\% kepada Nasabah berprestasi. Kriteria "Berprestasiee adalah Nasabah dengan riwayat pembiayaan berkualitas lancar dan/atau dengan kemampuan dana mandiri melakukan pelunasan dipercepat. Riwayat kualitas pembiayaan lancar merupakan prestasi. Melunasi pembiayaan dengan dana mandiri bukan berasal dari dana take over pembiayaan Bank lain juga merupakan prestasi yang seharusnya dihargai oleh Bank. Nasabah Berprestasi yang mendapatkan keringanan, bukan tidak mungkin akan menjadi Nasabah Prima dan Loyal bagi Bank Pembangunan Syariah. Kondisi tersebut adalah dampak dari tercapainya 2 (dua) kesepakatan dalam bisnis keuangan yang dilakukan Bank Pembangunan Syariah, kesepakatan harga dan kesepakatan rasa keadilan.

\section{Pembiayaan Murabahah Produktif Mikro (Single Rate - Anuitas)}

Pembiayaan Murabahah Produktif Mikro adalah penyediaan untuk kebutuhan modal kerja dan investasi usaha dengan limit mulai dari Rp 25.000.000,00 s/d Rp 500.000.000,00. Tenor yang ditawarkan umumnya maksimal 3 tahun dengan pola angsuran bulanan.

Simulasi angsuran pembiayaan dengan limit $\mathrm{Rp} 100.000 .000,00$ selama 3 tahun (mulai 1 Januari 2018) dengan pengakuan keutungan secara anuitas setara $20 \%$ eff/p.a, sebagai berikut ;

Tabel 7 Simulasi Angsuran Pembiayaan Murabahah Produktif Mikro

\begin{tabular}{|l|r|}
\hline \multicolumn{2}{|c|}{ Pembiayaan Murabahah Produktif Mikro } \\
\hline A. Harga Perolehan & 100.000 .000 \\
\hline B. Margin & 33.788 .900 \\
\hline C. Harga Jual & 133.788 .900 \\
\hline D. Uang Muka Nasabah & - \\
\hline E. Piutang Murabahah & 133.788 .900 \\
\hline & \\
\hline F. Pembiayaan Bank & 100.000 .000 \\
\hline G. Angsuran : & 3.716 .358 \\
\hline
\end{tabular}




\begin{tabular}{|c|c|c|}
\hline PEMBIAYAAN & $100.000 .000,00$ & RUPIAH \\
\hline JANG & 36 & BULAN \\
\hline EQUIVALEN RATE MARGIN & $20,00 \%$ ANGSURAN : & 3.716 .358 \\
\hline
\end{tabular}

\begin{tabular}{|r|r|r|r|r|r|r|r|}
\hline \multicolumn{4}{|c|}{ Jadwal Angsuran Kepada Nasabah } & \multicolumn{4}{|c|}{ Internal Akuntansi Bank (Anuitas) } \\
\hline No. & Bulan & Hutang Nasabah & Angsuran & Ang. Pokok & Ang. Margin & \multicolumn{1}{|c|}{ Pokok } & \multicolumn{1}{c|}{ Margin } \\
\hline & Jan-18 & 133.788 .900 & & & & 100.000 .000 & 33.788 .900 \\
\hline 1 & Feb-18 & 130.072 .542 & 3.716 .358 & 2.049 .692 & 1.666 .667 & 97.950 .308 & 32.122 .233 \\
\hline 2 & Mar-18 & 126.356 .183 & 3.716 .358 & 2.083 .853 & 1.632 .505 & 95.866 .455 & 30.489 .728 \\
\hline 3 & Apr-18 & 122.639 .825 & 3.716 .358 & 2.118 .584 & 1.597 .774 & 93.747 .871 & 28.891 .954 \\
\hline 4 & Mei-18 & 118.923 .467 & 3.716 .358 & 2.153 .894 & 1.562 .465 & 91.593 .977 & 27.329 .490 \\
\hline 5 & Jun-18 & 115.207 .108 & 3.716 .358 & 2.189 .792 & 1.526 .566 & 89.404 .185 & 25.802 .923 \\
\hline 6 & Jul-18 & 111.490 .750 & 3.716 .358 & 2.226 .289 & 1.490 .070 & 87.177 .897 & 24.312 .853 \\
\hline 7 & Agust-18 & 107.774 .392 & 3.716 .358 & 2.263 .393 & 1.452 .965 & 84.914 .503 & 22.859 .869 \\
\hline 8 & Sep-18 & 104.058 .033 & 3.716 .358 & 2.301 .117 & 1.415 .242 & 82.613 .387 & 21.444 .647 \\
\hline 9 & Okt-18 & 100.341 .675 & 3.716 .358 & 2.339 .469 & 1.376 .890 & 80.273 .918 & 20.067 .757 \\
\hline 10 & Nop-18 & 96.625 .317 & 3.716 .358 & 2.378 .460 & 1.337 .899 & 77.895 .458 & 18.729 .858 \\
\hline 11 & Des-18 & 92.908 .958 & 3.716 .358 & 2.418 .101 & 1.298 .258 & 75.477 .358 & 17.431 .601 \\
\hline 12 & Jan-19 & 89.192 .600 & 3.716 .358 & 2.458 .402 & 1.257 .956 & 73.018 .955 & 16.173 .645 \\
\hline 13 & Feb-19 & 85.476 .242 & 3.716 .358 & 2.499 .376 & 1.216 .983 & 70.519 .580 & 14.956 .662 \\
\hline 14 & Mar-19 & 81.759 .883 & 3.716 .358 & 2.541 .032 & 1.175 .326 & 67.978 .547 & 13.781 .336 \\
\hline 15 & Apr-19 & 78.043 .525 & 3.716 .358 & 2.583 .383 & 1.132 .976 & 65.395 .165 & 12.648 .360 \\
\hline 35 & Des-20 & 3.716 .358 & 3.716 .358 & 3.595 .509 & 120.849 & 3.655 .434 & 60.924 \\
\hline 36 & Jan-21 & $(0,00)$ & 3.716 .358 & 3.655 .434 & 60.924 & $(0,00)$ & $(0,00)$ \\
\hline & & & $20,00 \%$ & & & & \\
\hline
\end{tabular}

Pelunasan dipercepat Pembiayaan Murabahah Produktif Mikro di Bank Pembangunan Syariah berlaku ketentuan ;

\section{Pelunasan sebelum 6 Bulan Pelunasan setelah 6 Bulan}

Nilai pelunasan dihitung sebesar sisa Nilai pelunasan dihitung sebesar sisa pokok pembiayaan ditambah 2 kali pokok pembiayaan ditambah 1 kali angsuran angsuran, namun tidak boleh melebihi jumlah hutang sebagaimana perjanjian awal.

Skenario pelunasan pembiayaan dipercepat dilakukan di bulan ke-5 dan bulan ke-11 dengan simulasi sebagai berikut ;

Tabel 8 Simulasi Pelunasan Dipercepat Sebelum 6 Bulan Pembiayaan Murabahah Produktif Mikro dengan 2 skenario pelunasan 


\begin{tabular}{|c|c|c|}
\hline \multicolumn{3}{|c|}{ Pelunasan Dipercepat } \\
\hline \multicolumn{3}{|l|}{ Bulan } \\
\hline 1 & 3.716 .358 & \\
\hline 2 & 3.716 .358 & \\
\hline 3 & 3.716 .358 & \\
\hline 4 & 3.716 .358 & \\
\hline 5 & 99.026 .694 & \\
\hline IRR & $33,96 \%$ & \\
\hline \multicolumn{2}{|c|}{ Sisa Pokok Bulan Ke-4 } & 91.593 .977 \\
\hline \multicolumn{3}{|c|}{$2 x$ angsuran } \\
\hline \multicolumn{2}{|c|}{ Angsuran Bulan Ke-5 } & 3.716 .358 \\
\hline \multicolumn{2}{|c|}{ Angsuran Bulan Ke-6 } & 3.716 .358 \\
\hline \multicolumn{2}{|c|}{ Nilai Pelunasan } & 99.026 .694 \\
\hline \multicolumn{2}{|c|}{ Potongan Pelunasan } & 19.896 .773 \\
\hline
\end{tabular}

\begin{tabular}{|c|c|c|}
\hline \multicolumn{3}{|c|}{$\begin{array}{c}\text { Pelunasan Dipercepat } \\
\text { Skenario sisa pokok pembiayaan + } \\
1 \text { (satu) kali margin }\end{array}$} \\
\hline \multicolumn{3}{|l|}{ Bulan } \\
\hline 1 & 3.716 .358 & \\
\hline 2 & 3.716 .358 & \\
\hline 3 & 3.716 .358 & \\
\hline 4 & 3.716 .358 & \\
\hline 5 & 93.120 .544 & \\
\hline IRR & $20,00 \%$ & \\
\hline \multirow{2}{*}{\multicolumn{2}{|c|}{$\begin{array}{l}\text { Sisa Pokok Bulan Ke-4 } \\
\text { Margin Bulan Ke - } 5\end{array}$}} & 91.593 .977 \\
\hline & & 1.526 .566 \\
\hline \multicolumn{2}{|c|}{ Nilai Pelunasan } & 93.120 .544 \\
\hline \multicolumn{2}{|c|}{ Potongan Pelunasan } & 25.802 .923 \\
\hline
\end{tabular}

Tabel 9 Simulasi Pelunasan Dipercepat Setelah 6 Bulan Pembiayaan Murabahah Produktif Mikro dengan 2 skenario pelunasan

\begin{tabular}{|c|r|r|}
\hline \multicolumn{3}{|c|}{ Pelunasan Dipercepat } \\
\hline Bulan & & \\
\hline 1 & 3.716 .358 & \\
\hline 2 & 3.716 .358 & \\
\hline 3 & 3.716 .358 & \\
\hline 4 & 3.716 .358 & \\
\hline 5 & 3.716 .358 & \\
\hline 6 & 3.716 .358 & \\
\hline 7 & 3.716 .358 & \\
\hline 8 & 3.716 .358 & \\
\hline 9 & 3.716 .358 & \\
\hline 10 & 3.716 .358 & \\
\hline 11 & 3.716 .358 & \\
\hline 12 & 79.193 .716 & \\
\hline IRR & $22,50 \%$ & \\
\hline Sisa Pokok Bulan Ke-11: & 75.477 .358 \\
\hline Angsuran Bulan Ke-12 & 3.716 .358 \\
\hline Nilai Pelunasan & $:$ & 79.193 .716 \\
\hline Potongan Pelunasan & 13.715 .242 \\
\hline
\end{tabular}

\begin{tabular}{|c|c|c|}
\hline $\begin{array}{c}\text { Pelunasan Dipercepat } \\
\text { Skenario sisa pokok pembiayaan } \\
\text { 1 (satu) }\end{array}$ \\
\hline kali margin
\end{tabular}

Kebijakan sisa pokok pembiayaan ditambah 2 (dua) kali angsuran untuk pelunasan sebelum 6 bulan, berdampak pada meningkatnya nilai RR dari semula 20,00\% menjadi 33,96\%. Nasabah diwajibkan menyelesaikan tagihan pelunasan sebesar $\mathrm{Rp}$ 99.026.694. Kebijakan lain, yaitu sisa pokok pembiayaan ditambah 1 (satu) kali angsuran untuk pelunasan setelah 6 bulan juga berdampak pada meningkatnya nilai IRR dari semula $20,00 \%$ menjadi 22,50\%. Nasabah diwajibkan menyelesaikan tagihan pelunasan sebesar Rp 79.193.716.

Bank Pembangunan Syariah tidak menerapkan kebijakan yang sama untuk pelunasan dipercepat Pembiyaan Murabahah Produktif Mikro sebagaimana produk Pembiayaan Murabahah Program Khusus. 
Dasar pertimbangannya adalah pencapaian target keuntungan dikarenakan produk ini masuk kategori berisiko tinggi. Bank menyatakan bahwa alokasi keuntungan digunakan untuk mengcover biaya dari asuransi pembiayaan (penjaminan).

Berangkat dari perspektif persamaan angka RR pelunasan dan RR awal, penulis menyimpulkan dua kebijakan pelunasan dipercepat produk Pembiayaan Murabahah Produktif Mikro telah mecederai azas keadilan dari sisi Nasabah. Lazimnya seluruh lembaga bisnis fokus kepada pencapaian keuntungan. Namun demikian, Bank Pembangunan Syariah perlu mempertimbangkan klasifikasi Nasabah yang melakukan pelunasan dipercepat sebagaimana analisa sub bab Pembiayaan Murabahah Properti. Nasabah kategori berprestasi pada Pembiayaan Murabahah Produktif Mikro seharusnya bisa mendapatkan kebijakan pelunasan dengan perhitungan sisa pokok pembiayaan ditambah 1 (satu) kali margin. Berdasarkan simulasi, dalam kondisi apa pun (pelunasan sebelum maupun setelah 6 bulan) nilai pelunasan yang ditetapkan Bank dengan perhitungan ini akan lebih meringankan Nasabah dengan angka RR yang tetap terjaga di posisi $20,00 \%$.

Tabel 10 Perbandingan Nilai Pelunasan Untuk Alternatif Nasabah Berprestasi

\begin{tabular}{|c|c|c|c|c|c|}
\hline Klasifikasi & Kebijakan & $\begin{array}{c}\text { Nilai } \\
\text { Pelunasan }\end{array}$ & $\begin{array}{c}\text { RR } \\
\text { Pelunasan }\end{array}$ & $\begin{array}{c}\mathrm{RR} \\
\text { Awal }\end{array}$ & Selisih (A-B) \\
\hline $\begin{array}{l}\text { Pelunasan sebelum } \\
6 \text { Bulan (A) }\end{array}$ & \begin{tabular}{|lr} 
sisa & pokok \\
pembiayaan & ditambah \\
2 (dua) & kali angsuran
\end{tabular} & 99.026 .694 & $33,96 \%$ & $20,00 \%$ & \multirow{2}{*}{5.906 .150} \\
\hline $\begin{array}{l}\text { Alternatif Nasabah } \\
\text { Berprestasi (B) }\end{array}$ & $\begin{array}{|lr|}\text { sisa } & \text { pokok } \\
\text { pembiayaan } & \text { ditambah } \\
1 \text { (satu) } & \text { kali margin }\end{array}$ & 93.120 .544 & $20,00 \%$ & $20,00 \%$ & \\
\hline
\end{tabular}

\begin{tabular}{|c|c|c|c|c|c|}
\hline Klasifikasi & Kebijakan & $\begin{array}{c}\text { Nilai } \\
\text { Pelunasan }\end{array}$ & $\begin{array}{c}\text { RR } \\
\text { Pelunasan }\end{array}$ & $\begin{array}{c}\mathrm{RR} \\
\text { Awal }\end{array}$ & Selisih (A-B) \\
\hline $\begin{array}{l}\text { Pelunasan setelah } \\
6 \text { Bulan (A) }\end{array}$ & $\begin{array}{|lr|}\text { sisa } & \text { pokok } \\
\text { pembiayaan } & \text { ditambah } \\
2 \text { (dua) } & \text { kali angsuran } \\
\end{array}$ & 79.193 .716 & $22,50 \%$ & $20,00 \%$ & \multirow{2}{*}{2.458 .402} \\
\hline $\begin{array}{l}\text { Alternatif Nasabah } \\
\text { Berprestasi (B) }\end{array}$ & $\begin{array}{|lr|}\text { sisa } & \text { pokok } \\
\text { pembiayaan } & \text { ditambah } \\
1 \text { (satu) } & \text { kali margin } \\
\end{array}$ & 76.735 .314 & $20,00 \%$ & $20,00 \%$ & \\
\hline
\end{tabular}

\section{Pembiayaan Murabahah Produktif Ritel (Single Rate - Anuitas)}

Pembiayaan Murabahah Produktif Ritel adalah penyediaan dana untuk kebutuhan modal kerja dan investasi usaha dengan limit mulai dari di atas Rp $500.000 .000,00 \mathrm{~s} / \mathrm{d} \mathrm{Rp} 10.000 .000 .000,00$. Tenor yang ditawarkan umumnya maksimal 5 tahun dengan pola angsuran bulanan. Pelunasan dipercepat pembiayaan ini sama dengan Pembiayaan Murabahah Program Khusus yaitu sisa pokok pembiayaan ditambah 1 (satu) kali margin. Kebijakan ini juga ditetapkan dalam Standar Operasi Prosedur Bank.

Bank Pembangunan Syariah telah menerapkan asas keadilan dalam pelunasan dipercepat. Simulasi IRR untuk kebijakan pelunasan dengan perhitungan 
sisa pokok pembiayaan ditambah 1 (satu) kali margin akan menghasilkan nilai RR pelunasan yang sama dengan RR awal. Silahkan merujuk pada simulasi pelunasan dipercepat Pembiayaan Murabahah dengan kebijakan "sisa pokok pembiayaan ditambah 1 (satu) kali margin".

\section{Pembiayaan Murabahah Produktif Korporasi (Single Rate - Anuitas)}

Pembiayaan Murabahah Produktif Korporasi adalah penyediaan dana untuk kebutuhan modal kerja dan investasi usaha dengan limit mulai dari di atas Rp 10.000.000.000,00 s/d limit Batas Maksmimum Pemberian Kredit/Pembiayaan (BMPK). Tenor yang ditawarkan sangat variatif bergantung pada kebutuhan dan model bisnis dari Nasabah.

Pelunasan dipercepat pembiayaan ini sama dengan Pembiayaan Murabahah Program Khusus yaitu sisa pokok pembiayaan ditambah 1 (satu) kali margin. Namun demikian, kebijakan tersebut tidak dokumentasikan pada Standar Operasi Prosedur dan/atau Surat Petunjuk Teknis. Petugas Bank biasanya akan melakukan negosiasi (business to business) jika nasabah akan melakukan pelunasan dipercepat. Menurut keterangan responden, umumnya bank menetapkan pelunasan dengan sisa pokok pembiayaan ditambah 1 (satu) kali margin.

Bank Pembangunan Syariah telah menerapkan asas keadilan dalam pelunasan dipercepat. Simulasi IRR untuk kebijakan pelunasan dengan perhitungan sisa pokok pembiayaan ditambah 1 (satu) kali margin akan menghasilkan nilai RR pelunasan yang sama dengan RR awal. Silahkan merujuk pada simulasi pelunasan dipercepat Pembiayaan Murabahah dengan kebijakan "sisa pokok pembiayaan ditambah 1 (satu) kali margin".

\section{KESIMPULAN}

Praktik bisnis keuangan syariah dijamin oleh undang-undang, dari sisi perundang-undangan tidak ada yang dilanggar dalam seluruh skema pembiayaan murabahah, namun lain halnya bila nasabah melakukan pelunasan dipercepat, bila berpatokan pada perhitungan matematis, akan berpotensi menciderai azas keadilan, hal ini tidak sejalan dengan prinsip Bank Syariah yang berazaskan Islami. Oleh sebab itu Bank Syariah harus mampu menerapkan azas keadilan untuk semua pihak, baik kepentingan konsumen (nasabah) dan pelaku usaha (bank syariah). Keadilan berarti kepentingan konsumen dan pelaku usaha dapat diwujudkan secara maksimal dan memberikan kesempatan kepada mereka untuk memperoleh hak dan melaksanakan kewajiban masing-masing secara adil. Dalam persoalan pelunasan dipercepat pembiayaan murabahah, keadilan dapat diterjemahkan dengan menetapkan jumlah pelunasan yang tidak memberatkan Nasabah dan tidak merugikan Bank Syariah.

Kebijakan pelunasan dipercepat Bank Pembangunan Syariah tidak sama untuk setiap produk. Namun demikian, Penulis menyimpulkan Bank Pembangunan Syariah mampu menterjemahkan asas keadilan dalam pelunasan dipercepat pembiayaan murabahah. Parameter kesimpulan ini adalah; i) bank telah mengimplementasikan kebijakan pelunasan dipercepat dalam suatu dokumen 
perusahaan; Standar Operasi Prosedur dan/atau Surat Petunjuk Teknis dan ii) kebijakan jumlah pelunasan yang ditetapkan tidak memberatkan nasabah. Pada produk pembiayaan murabahah ; Program Khusus, Ritel dan Korporasi, angka IRR pelunasan adalah sama dengan IRR pada awal akad pembiayaan.

\section{Implikasi dan Keterbatasan}

Hasil Penelitian hanya fokus pada fakta dari satu Bank Syariah. Hal tersebut menjadi keterbatasan dari penelitian ini. Oleh sebab itu, terbuka peluang untuk dilakukan kajian dan observasi yang lebih luas ke berbagai lembaga keuangan syariah yang menyalurkan pembiayaan berdasarkan skema Murabahah.

\section{DAFTAR PUSTAKA}

Accounting and Auditing Organization for Islamic Financial Institutions. (2015). Shari'a Standards. Kingdom of Bahrain.

Anas, Irham Fachreza. (2018). Titik Kritis Pelunasan Sebelum Jatuh Tempo Pembiayaan. Jurnal Akuntansi Berkelanjutan Indonesia Vol 1. Universitas Pamulang

Anas, Irham Fachreza. (2016). Lingkaran Setan KPR dan Keadilan Dalam Pelunasan Pembiayaan Murabahah. https https://irhamanas.blogspot.com/2016/08/membedah-logika-bank-syariah-sesi-3.html

Al-Zuhaili, Wahbah. (2008). Al-Fiqh Al-islami Wa Adillatuhu, Juz 4. Damaskus. Dar Fikr al-Mu'asir.

Budianto, Aris. (2007). Modul Praktikum KKPI Microsoft Excel 2007 - Untuk Kelas : X Semester 2. Sidareja. SMK Tamtama 1 Sidareja.

Ikatan Bankir Indonesia. (2014). Memahami Bank Syariah - Modul Sertifikasi Tingkat I General Banking Syariah. Jakarta. PT Gramedia Pustaka Utama.

Ikatan Bankir Indonesia. (2015). Mengelola Bisnis Pembiayaan Bank Syariah Modul Sertifikasi Pembiayaan Syariah I. Jakarta. PT Gramedia Pustaka Utama.

Moleong, Lexy.J. (2006). Metode Penelitian Kualitatif, (Eds). Bandung. PT Remaja Rosda Karya.

Otoritas Jasa Keuangan. (2016). Standar Produk Murabahah. Jakarta

Otoritas Jasa Keuangan. (2018). Statistik Perbankan Syariah - Juni 2018. Jakarta

Sahroni, Oni, Hasanuddin. (2016). Fikih Muamalah ; Dinamika Teori Akad dan Implementasinya dalam Ekonomi Syariah. Jakarta. Rajawali Press.

Soemitra, Andri. (2010). Bank \& Lembaga Keuangan Syariah. Jakarta. Kencana.

Supriyanto, Trisiladi. (2014). Konsep Rate of Profit Perspektif Ekonomi Islam. Disertasi S3. Sekolah Pasca Sarjana Universitas Islam Negeri Syarif Hidayatullah.

Tarmizi, Erwandi. (2016). Harta Haram Muamalat Kontemporer. Bogor. PT. Berkat Mulia Insani.

Walsh, Ciaran. (2012). Key Management Ratios Edisi Keempat.. Penerjemah Agus Dharma. Jakarta. Esensi Erlangga Group. 


\section{Peraturan Perundangan Undangan}

Undang - Undang nomor 7 tahun 1992 tentang Perbankan

Undang - Undang nomor 10 tahun 1998 tentang perubahan UU No 7/1992 tentang Perbankan

Undang - Undang nomor 21 tahun 2008 tentang Perbankan Syariah

Fatwa Dewan Syariah Nasional Majelis Ulama Indonesia (DSN-MUI) No. 04/DSN-MUI/IV/2000 tanggal 1 April 2000 tentang Murabahah.

Fatwa Dewan Syariah Nasional Majelis Ulama Indonesia (DSN-MUI) No. 46/DSN-MUI/II/2005 tanggal 17 Februari 2005 tentang Potongan Tagihan Murabahah (Khashm Fi Al-Murabahah).

Fatwa Dewan Syariah Nasional Majelis Ulama Indonesia (DSN-MUI) No. 84/DSN-MUI/XII/2012 tanggal 21 Desember 2012 tentang Metode Pengakuan Keuntungan Al-Tamwil Bi Al-Murabahah (Pembiayaan Murabahah) Di Lembaga Keuangan Syariah.

Fatwa Dewan Syariah Nasional Majelis Ulama Indonesia (DSN-MUI) No. 85/DSN-MUI/XII/2012 tanggal 21 Desember 2012 tentang Janji (Wa'D) Dalam Transaksi Keuangan dan Bisnis Syariah.

Fatwa Dewan Syariah Nasional Majelis Ulama Indonesia (DSN-MUI) No. 110/DSN-MUI/IX/2017 tanggal 19 September 2017 tentang Akad Jual Beli

Fatwa Dewan Syariah Nasional Majelis Ulama Indonesia (DSN-MUI) No. 111/DSN-MUI/IX/2017 tanggal 19 September 2017 tentang Akad Jual Beli Murabahah

Surat Edaran Otoritas Jasa Keuangan Nomor 36/SEOJK.03/2015 tanggal 21 Desember 2015 Tentang Produk dan Aktivitas Bank Syariah dan Unit Usaha Syariah. 